\title{
Effect of salinity on the germination of three varieties of Phaseolus vulgaris L. (Fabales Fabaceae)
}

\author{
Bennabi Farid ${ }^{*}$, Belkhodja Moulay ${ }^{2}$, Boukraa Djamila³ \& Rahmani Khaled ${ }^{4}$ \\ ${ }^{1}$ University Centre of Belhadj Bouchaib, N95, Aïn Témouchent, Algeria \\ ${ }^{2}$ Laboratory of Plant Physiology, Department of Biology, Faculty of Sciences, University of Oran1 Ahmed Benbella, Algeria \\ ${ }^{3}$ Laboratoire de Recherche sur les Systèmes Biologiques et la Géomatique, Faculté des Sciences de la Nature et de la Vie, \\ Université de Mascara, P.O. Box 305, Mascara, Algeria \\ ${ }^{4}$ University of Sidi Belabbes, Djilali Lyabes, laboratoire Ecodéveloppement des espaces, Algeria \\ *Corresponding author, email: bennabi.farid@yahoo.fr
}

ABSTRACT

The present study is carried out to compare tolerance levels towards salinity of three varieties of the plant Phaseolus vulgaris L. (Fabales Fabaceae): Cocorose, Eldjadida and Tadalaghte (a Saharan variety harvested from the area of Béchar in the south of Algeria) during germination. The tolerance levels are estimated by percentage of germinated seeds as well as of the length of roots (in $\mathrm{cm}$ ), during a period of eight days. Preliminary results show that the germination is maximal in the distilled water and decreases with the increase of the salt concentration of the environment. It is non-existant at 300 meq of $\mathrm{NaCl}$ in all the varieties. The increase of the salt concentration delays the germination and reduces percentage of germinated seeds. The response of the seeds of $P$. vulgaris towards the saline stress varies depending on time and salt concentration. The effect of $\mathrm{NaCl}$ on germination varies also depending on the variety. It was found that the variety Tadalaghte shows a good tolerance towards salinity better than Eldjadida and Cocorose. The latter is the most sensitive variety.

KEY WORDS Salinity; bean; germination; Cocorose; Tadalaghte; Eldjadida.

Received 23.03.2019; accepted 02.07.2019; published online 20.08.2019.

\section{INTRODUCTION}

The common bean, Phaseolus vulgaris L. (Fabales Fabaceae), is the most consumed species in the world. It is a source of food and energy and it takes the first place of consumed leguminous plants in front of the pea, the chickpea, the Black-eyed pea and the broad bean. In 2006, the world production of bean rose to 28.6 million metric tons, of which 19.6 million metric tons of dry beans (68\%), 6.04 million metric tons of fresh beans $(22 \%)$, and 2.6 million metric tons of green beans ( $9 \%$ ). In 2002, these total numbers were respectively $25.7,18.3,1.7$ million metric tons (F.A.O., 2006).
Between 1961 and 2006, the total production of bean has doubled from 14.4 to 28.6 million metric tons (F.A.O., 2006).

In Algeria, the leguminous plants are an important food, after cereals, but its production is still weak, and often our country resorts to the importation of this product. The cost of leguminous plants importation comes to 355 million dollars (Azouz, 2009).

This weak agricultural production justifies itself mainly by the persistence of abiotic constraints. "Abiotic stress" is a general term that includes numerous constraints such as the heat, the cold, the dryness, the excess of light, the UV-B radiation, the 
water excess, the salinity, the harmful practices, the exposure to ozone and the osmotic impact; the arable soils subject to abiotic stress are estimated at 90\% (Dita et al., 2006).

In arid and semi-arid regions, the soil salinity oppose the plants development (Lauchli \& Eptein, 1990; Higazy et al., 1995; Abuelgasima \& Ammad, 2019) and it is a threat to the diet balance (Kinet et al., 1998). Current data in the Mediterranean basin show 16 million hectares of salted soils of which 3.2 million are in Algeria (Hamdy, 1999, 2005).

In these soils, certain species are threatened to disappear (Chamard, 1993; James et al., 2003), while others show adaptation mechanisms (Batanouny, 1993, 2001) expressed by modifications in the cellular metabolism (Hare \& Cress, 1997; Krasensky and al., 2012). In fact, in salted environments, plants adjust osmotically their cellular contents (Goldhirs et al., 1990). Proline accumulation is one of the most frequent adaptive strategies (Belkhodja \& Benkablia, 2000; Ashraf \& McNeilly, 2004; Bennabi, 2005; Boukraa, 2008; Bennabi, 2017).

Only the helophyte plants, such as Salicornia, blossom on a soil rich in salts. Most of the grown plants belong to species that are sensitive to salinity (Levigneron et al., 1995; Flowers et al., 2010).

The common bean, Phaseolus vulgaris L. (Fabales Fabaceae), is extremely sensitive to salinity and it was valued that about 5 to $30 \%$ of bean production zones are affected by the salinity of the soil (CIAT, 1992; Gama et al., 2007).

The salinity of the soil can inhibit the growth and the yield of the bean because of an ionic toxicity and for a decrease of the hydric potential of the plant (Ashraf, 1997; Ahmad et al., 2012).

The present study aims at assessing the effect of the saline stress on the germination of three varieties of P. vulgaris (Cocorose, Eldjadida and Tadalaghte, a Saharan variety harvested from the area of Béchar in the south of Algeria), in order to determine the most resistant variety to salinity.

\section{MATERIAL AND METHODS}

For the germination, the tests were carried out on three varieties of the bean, $P$. vulgaris: borlotti (Cocorose), black (Eldjadida) and Tadalaghte (Saharan variety).
Seeds were disinfected using hypochlorite sodium solution at $0.5 \%$ during 5 minutes then were rinsed with distilled water several times.

In order to determine the harmful effects of salinity on germination of the bean seeds, a germination test was carried out under different concentrations of sodium chloride.

Seeds of every variety, borlotti variety (Cocorose), black variety (Eldjadida), and the local variety (Tadalaghte) were put to germinate in knead boxes ( 25 seeds in each box) upholstered with a double layer of sterilized filter and with $25 \mathrm{ml}$ of distilled water and $25 \mathrm{ml}$ of saline solution $(50 \mathrm{meq}$, $150 \mathrm{meq}, 300 \mathrm{meq})$. Boxes were arranged in an incubator at hold a temperature of $25 \pm 1^{\circ} \mathrm{C}$.

Knead boxes were watered every 2 days to keep seeds always soaked in solution.

\section{RESULTS}

The figure 1 shows variations of germination kinetics in the Cocorose variety (borlotti bean) put under stress of salinity in different concentrations of $\mathrm{NaCl}$ saline solution (50 meq, $150 \mathrm{meq}$ and 300 meq) during 24 hours, 48 hours, 72 hours and 8 days. We have noticed that the appearance of the radicle was only after 72 hours for sample seeds and those which had received 50 meq of saline concentration. While in 150 meq germination was almost on the eighth day, it did not occur with seeds treated with the concentration of 300 meq.

The percentage of the germinated seeds, during 8 days, was $30 \%$ for samples against $22 \%$, with 50 meq of $\mathrm{NaCl}, 6 \%$ with 150 meq of $\mathrm{NaCl}$ and $0 \%$ with 300 meq concentration.

Study of the germination test of Cocorose variety, expressed in percentage of geminated seeds (Fig. 2), shows a negative correlation between the percentage of germinated seeds and the degree of salinity.

Figure 3 shows variations of the germination in Eldjadida variety (black bean). We observe the appearance of radicle after 48 hours for sample seeds and seeds treated with 50 meq with a weak increase for sample seeds $(1.27 \mathrm{~cm}$ against $0.55 \mathrm{~cm})$.

In seeds treated with 150 meq of $\mathrm{NaCl}$, the germination began only 72 hours after, while seeds treated with 300 meq do not develop even 8 days after. Generally, germination decreases with the increase of salinity in this variety. 


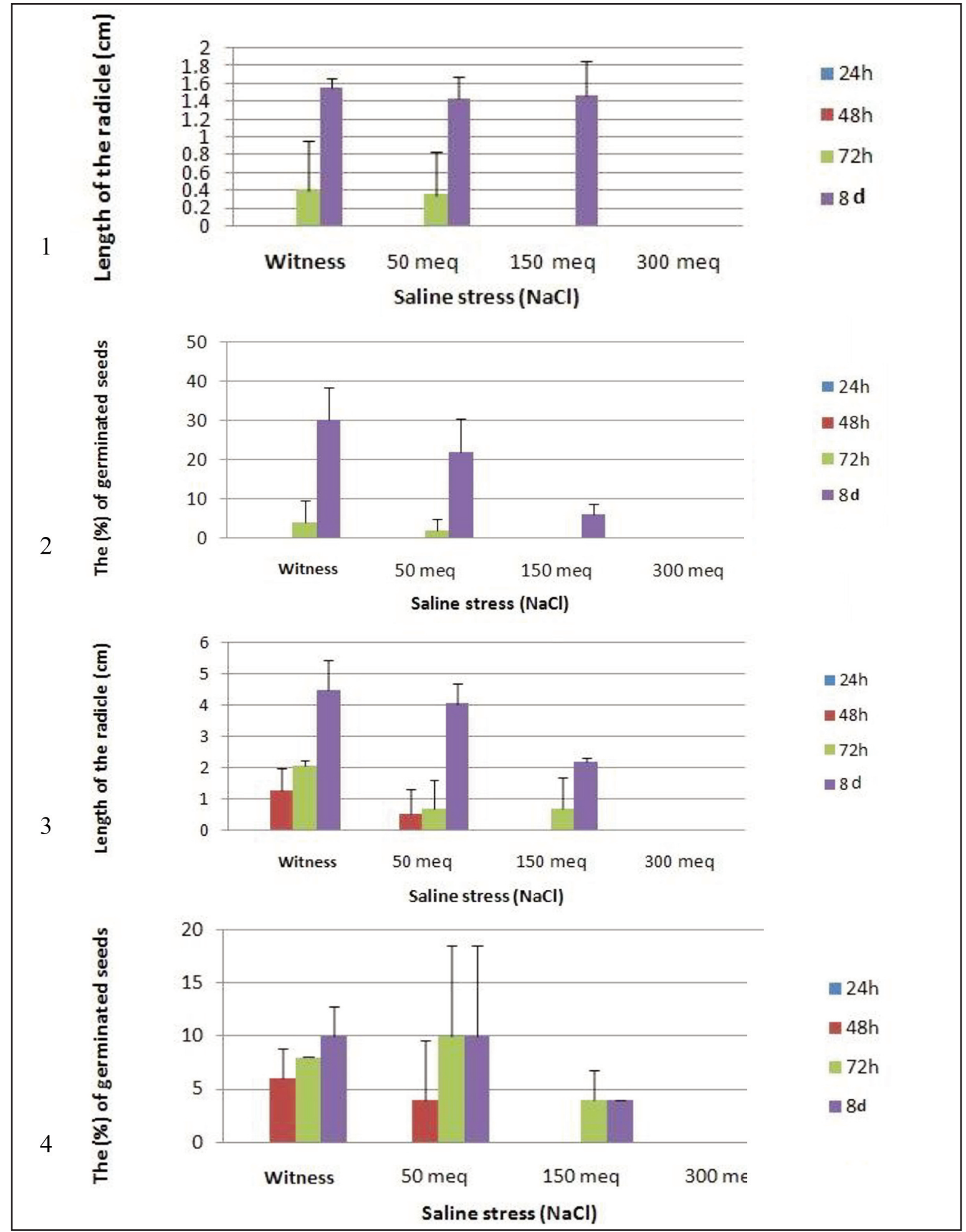

Figure 1. Variations of germination expressed in length of radicle in $(\mathrm{cm})$ in Cocorose variety (borlotti bean) put under stress of salinity. Figure 2. Variations of germination expressed in percentage (\%) of germinated seeds in the cocorose variety (borlotti variety) put under stress of salinity. Figure 3. Variations of germination expressed in length of radicle in $(\mathrm{cm})$ in Eldjadida variety (black bean) put under stress of salinity, according to time. Figure 4. Variations of germination expressed in percentage (\%) of germinated seeds in Eldjadida variety (black bean) put under stress of salinity. 
According to the figure 4, we can notice that percentages of germinated seeds in Eldjadida variety are similar for sample seeds and seeds treated with 50 meq of $\mathrm{NaCl}$, with a weak alternation after 24 hours and 72 hours. On the other hand, in seeds soaked in a 150 meq saline solution, germination was only after 72 hours and with a reduced percentage comparing to sample seeds. This percentage remains the same 8 days after. In seeds treated with 300 meq, we have no germinationt even 8 days after.

Figure 5 indicates that there is a difference in Tadalaghte variety (Saharan bean) compared to the two previous varieties. We have noticed that the length of radicle is almost the same in the sample seeds and those treated with 50 and 150 meq of $\mathrm{NaCl}$, after 48 hours and 72 hours. The effect of the saline stress appears only 8 days after. Moreover, we have noticed that the treatment of seeds with 300 meq, shows the appearance of the radicle after 8 days, contrary to the two previous varieties where we have recorded no trace of germination in the same days.
Figure 6 shows that the percentage of germinated seeds in Tadalaghte variety is much higher than the percentage of germinated seeds of the two previous varieties, whatever the saline treatment is (sample, 50, $150 \mathrm{meq}$, and $300 \mathrm{meq}$ ).

\section{DISCUSSION AND CONCLUSIONS}

Results of the germination test applied on three varieties of $P$. vulgaris show there is a reduction in the germination rate with the increase of the saline concentration compared to the sample seeds, according to time. We can deduce that there is a negative correlation between the germination and the saline stress in this species. By comparing results of the three varieties, we can notice that the percentage of the germinated seeds is very raised in the Tadalaghte variety (Saharan bean) compared to Eldjadida variety (black bean) and Cocorose variety (borlotti bean).

We can notice that Tadalaghte variety is more adapted to salinity than the two other varieties, in

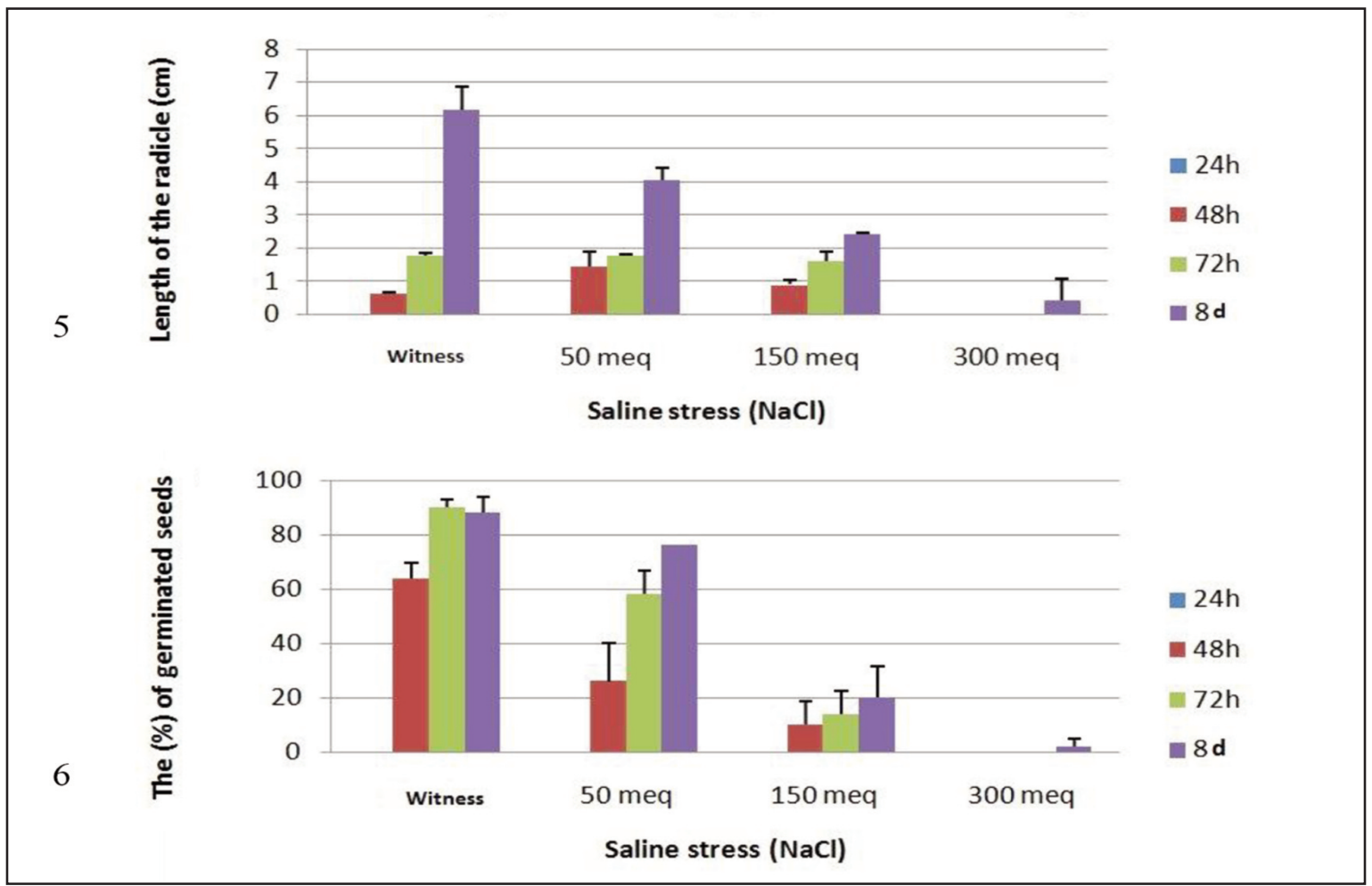

Figure 5. Variations of germination expressed in length of the radicle in $(\mathrm{cm})$ in Tadalaghte variety (Saharan variety) put under stress of salinity. Figure 6. Variations of germination expressed in percentage (\%) of germinated seeds in Tadalaghte variety (Saharan bean) put under stress of salinity. 
the germination phase (see also Debez et al., 2001; Maillard, 2001; Boulghalagh et al., 2006; Chang et al., 2010).

According to Prado et al. (2000), Ashraf (2008), and Hannachi et al. (2018), the reduction in the germination rate must be due to a developed osmotic dormancy process, under the stress conditions. Also, the conversion of carbohydrates to soluble sugars playing the role of osmotic regulation in the embryonic cells in the germination phase is inhibited (Botia et al., 1998; Rosa et al., 2009; Wang et al., 2013). This late would be due to the deterioration of enzymes and hormones in these seeds (Botia et al., 1998; Dkhil \& Denden, 2010; Fernández, 2016). There could also be difficulties with the hydration of seeds as a result of a high osmotic potential (Gill et al., 2003). The reduction in the osmotic potential of the soil solution reducte the enzymatic activities and favors a strong absorption of $\mathrm{Na}+$ compared to $\mathrm{K}+$ (Adel $\&$ Bader, 2002; El-Sayed et al., 2013; Chen et al., 2015).

\section{REFERENCES}

Abuelgasim A. \& Ammad R., 2019. Mapping soil salinity in arid and semi-arid regions using Landsat 8 OLI satellite data. Remote Sensing Applications: Society and Environment, 13: 415-425. https://doi.org/10. 1016/j.rsase.2018.12.010

Adel J. \& Bader J., 2002. Studies of some traits related to salinity tolerance in bread whaead (Triticum aestivum L.) proceeding of the International symposium on optium resources utilization in salt-affected Ecosystems in arid and semi arid region, Cairo, Egypt, 102 pp.

Ahmad P., Kumar A., Gupta A., Hu X., Hakeem K.R., Azooz M.M. \& Sharma S., 2012. Polyamines: Role in Plants Under Abiotic Stress. In: Ashraf M., Ozturk M., Ahmad M.S.A. \& Aksoy A. (Eds.), Crop Production for Agricultural Improvement. Springer, New York, USA., ISBN: 9789400741164, pp: 491-512.

Ashraf M., 1997. Improvement of salt tolerance in some native pulse crops. In: Jaiwal P.K., Singh R.P. \& Gulati A. (Eds.), Strategies for improvement of salt tolerance in higher plants. New Delhi, India: Oxford and IBH Publishing Co. Pvt. Ltd, pp. 413-434.

Ashraf M. \& McNeilly T., 2004. Salinity tolerance in Brassica oil seeds. Reviews in Plant Sciences, 23: 157-174.

Ashraf M., Athar H., Harris P.J.C. \& Kwon T.R., 2008. Some Prospective Strategies for Improving Crop Salt
Tolerance. Advances in Agronomy, 97: 45-110. https: //doi.org/10.1016/S0065-2113(07)00002-8

Azouz F., 2009. Les réponses morpho-physiologiques et biochimiques chez l'haricot (Phaseolus vulgaris L.) soumis à un stress hydrique. Thèse de magister, Université Oran 1 - Ahmed Ben Bella (Université EsSénia), $82 \mathrm{pp}$.

Batanouny K.H., 1993. Ecophysiology of halophytes and their traditional use in the Arab World. In: ChoukrAllah R. \& Hamdy A. (Eds.), Halophyte Utilization in Agriculture, Advanced Course on, Proceeding of a symposium in Agadir, Morocco, 12-26 September 1993. Agadir, Morocco: Symposium Proceedings. 37-70 pp.

Batanouny K.H., 2001. Plant in the deserts of the Middle East. Berlin, Heidelberg, New York: Springer, 193 pp.

Belkhodja M. \& Benkablia M., 2000. Proline response of faba bean (Vicia faba L.) under salt stress. Egyptian Journal of Agricultural Research, 78: 185-195.

Bennabi F., 2005. Métabolisme glucidique et azote chez une halophyte (Atriplex halimus L.) stressée à la salinité. Mémoire de magistère en physiologie végétale, Université Es-Senia Oran, 136 pp.

Bennabi F., 2017. Les marqueurs biochimiques de la résistance à la salinité chez Phaseolus vulgaris L. These de Doctorat Université d'Oran 1, Algeria, .

Botia P., Carvajal M., Cerda A. \& Martinez V., 1998. Response of eight Cucumis melo cultivars to salinity during germination and early vegetative growth. Agronomie, 18: 503-513.

Boukraâ D., 2008. Interaction acide sulfosalicylique et salinité sur la réponse de la proline et des variations minérales chez des plantes juvéniles d'Atriplex halimus L. stressée à la salinité. Memoire Université d'Oran Es-Senia, Faculte de Sciences, 92 pp.

Boulghalagh J., Berrcihi A., El Halouani H. \& Boukroute A., 2006. Effet des stress salin et hydrique sur la germination des graines du jojoba (Simmondsia chinensis (Link) Schneider). Recueil des résumés le Premier Congrès National sur l'Amélioration de production Agricole, Settat, Maroc, 24 pp.

Chamard P., 1993. Environnement et développement. Références particulières aux états sahéliens membres du CCILS. Sécheresse, 4: 172-328.

Chang C., Wang B., Shi L., Li Y., Duo L. \& Zhang W., 2010. Alleviation of salt stress-induced inhibition of seed germination in cucumber (Cucumis sativus L.) by ethylene and glutamate. Journal of Plant Physiology, 167: 1152-1156. https://doi.org/10.1016/j.jplph. 2010.03.018

Chen K., Li E., Li T., Xu C., Wang X., Lin H., Qin J.G. \& Chen L., 2015. Transcriptome and Molecular Pathway Analysis of the Hepatopancreas in the Pacific White Shrimp Litopenaeus vannamei under Chronic 
Low-Salinity Stress. PLoS One 10(7): e0131503. https://doi.org/10.1371/journal.pone.0131503

CIAT (Centro Internacional de Agricultura Tropical), 1992. Constraints to and opportunities for improving bean production: A planning document 1993-98 and achieving document 1987-92, Cali, Colombia: CIAT.

Debez A., Chaibi W. \& Bouzid S., 2001. Effet du NaCl et de régulateurs de croissance sur la germination d'Atriplex halimus L. Agriculture, 10: 8-135.

Dita M.A., Rispail N., Prats E., Rubiales D. \& Singh K.B., 2006. Biotechnology approaches to overcome biotic and abiotic stress constraints in legumes. Euphytica, 147: 1-24.

Dkhil B.B. \& Denden M., 2010. Salt Stress Induced Changes in Germination, Sugars, Starch and Enzyme of Carbohydrate Metabolism in Abelmoschus esculentus (L.) Moench Seeds. African Journal of Agricultural Research, 5: 1412-1418. Available online at http://www.academicjournals.org/AJAR

El-Sayed H. \& El Sayed A., 2013. Exogenous application of ascorbic acid for improve germination, growth, water relations, organic and inorganic components in tomato (Lycopersicon esculentum Mill.) plant under salt-stress. New York Science Journal, 6: 123-139.

F.A.O., 2006. Programme de cooperation technique. Programme de développement des productions fourragères et de l'élevage. Rapport de synthèse, $45 \mathrm{pp}$.

Fernández I.C.D., Luque E.G., Mercado F.G. \& Pedrosa W., 2016. Influence of temperature and salinity on the germination of Limonium tabernense Erben from Tabernas Desert (Almería, SE Spain). Flora-Morphology, Distribution, Functional Ecology of Plants 218: 68-74. https://doi.org/10.1016/j.flora.2015.12. 001

Flowers T.J., Galal H.K. \& Bromham L., 2010. Evolution of Halophytes: Multiple Origins of Salt Tolerance in Land Plants. Functional Plant Biology, 37, 604-612. http://dx.doi.org/10.1071/FP09269

Gama P.B.S., Inanaga S., Tanaka K. \& Nakazawa R., 2007. Physiological response of common bean (Phaseolus vulgaris L.) seedlings to salinity stress. African Journal of Biotechnology, 6: 79-88. Available online at http://www.academicjournals.org/AJB

Gill P.K., Sharma A.D. Singh P. \& Bhullar S.S., 2003. Changes in germination, growth and soluble sugar contents of Sorghum bicolor (L.) Moench seeds under various abiotic stresses. Plant Growth Regulation, 40: 157-162.

Goldhirs A.G., Hankamer B. \& Urs S.H., 1990. Hydroxyproline and praline content of cell walls of sunflower, peanut and cotton growth under salt stress. Plant Science, 69: 27-32.

Hamdy A., 1999. Saline irrigation assessment for a sustainable use. Saline irrigation. Halophyte production and utilization; Project $\mathrm{N}^{\circ} \mathrm{IC} 18$ CT 960055, pp.152226.

Hamdy A., Sardo V. \& Farrag K., 2005. Saline water in supplemental irrigation of wheat and barley under rainfed agriculture. Agricultural Water Management 78: 122-127. https://doi.org/10.1016/j.agwat.2005. 04.017

Hannachi S. \& Van Labeke M.-C., 2018. Salt stress affects germination, seedling growth and physiological responses differentially in eggplant cultivars (Solanum melongena L.). Scientia Horticulturae, 228: 56-65.

Hare P.D \& Cress W.A., 1997. Metabolic implications of stress induced proline accumulation in plants. Plant Growth Regulation, 21: 79-102. https://doi.org/10. 1023/A:1005703923347

Higazy M., Shehata M. \& Allam A., 1995. Proline relation to salinity of three sugar varieties. Egyptian Journal of Agricultural Research, 73: 175-189.

Kinet M., Benrebiha F.Z., Bouzid S., Lailcahar S. \& Dupuit P., 1998. Reseau Atriplex. Atelier biotechnologies et écologie pour une sécurité alimentaire accrue en régions arides et semi arides. Cahiers Agricultures, 7: 505-509.

Krasensky J. \& Jonak C., 2012. Drought, salt, and temperature stress-induced metabolic rearrangements and regulatory networks. Journal of Experimental Botany, 63: 1593-1608.

Lauchli L. \& Epstein E., 1990. Plant response to saline conditions. In: Tanji K.K. (Ed.), Agricultural Salinity Assessment and Management, pp.113-137.

Levigneron A., Lopez F., Vansuyt G., Berthomieu P., Fourcroy P. \& Casse-Delbart F., 1995. Les plantes face au stress salin. Cahiers Agricultures, 4: 263-273.

Maillard J., 2001. Le point sur l'Irrigation et la salinité des sols en zone aride: Risques et Recommandations. Handicap International, November 2001, 35 pp.

Prado F.F., Boero C., Gallardo M. \& Gonzalez J.A., 2000 Effect of $\mathrm{NaCl}$ on germination growth and soluble sugar content in Chenopodium quinoa Willd. Seeds. Botanical Bulletin of Academia Sinica, 41: 27-34.

Rosa M., Prado C., Podazza G., Interdonato R., González J.A., Mirna Hilal M. \& Prado F.E., 2009. Soluble sugars - Metabolism, sensing and abiotic stress. A complex network in the life of plants. Plant signaling \& Behavior, 4: 388-393. https://doi.org/10.4161/psb. 4.5.8294

Wang Y., Yang L., Zheng Z., Grumet R., Loescher W., Zhu J.K., Yang P., Hu Y. \& Chan Z., 2013. Transcriptomic and physiological variations of three Arabidopsis ecotypes in response to salt stress. PLoS One 8(7): e69036. https://doi.org/10.1371/journal.pone.00690 36 